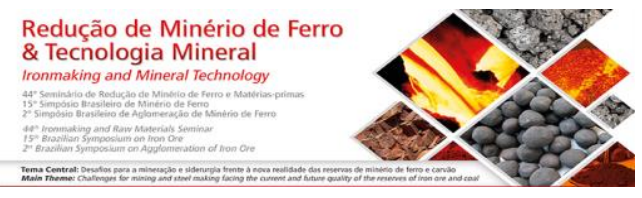

\title{
APPLICATIONS OF VERTIMILL IN GRINDING CIRCUITS*
}

\author{
Daniel Suarez ${ }^{1}$ \\ Vinícius Lisboa de Souza² \\ lan Dehart ${ }^{3}$
}

\begin{abstract}
Over the last few years the mining industry has continuously been facing increases in capital and operating costs for new projects; plant expansions and also significant increases in the operating costs of existing plants. To counteract such trend the industry is seeking technologies such as the Vertimill as an option to lower the operating costs of grinding circuits. The benefits the Vertimill offers in terms of lower energy consumption and lower media consumption are well established and documented; such benefits can significantly improve the viability of a new project, plant expansions or upgrading grinding mills that need to be replaced. The paper briefly describes the operation of the Vertimill, recent regrind applications in processing Iron ores where the impact of lower energy and grinding media consumption is very significant because of the large tonnages involved, and also applications as a tertiary and secondary grinding stages of grinding circuits. The paper also highlight the expected role the Vertimill can play in secondary applications and the expected impact on the overall economics of the project.
\end{abstract}

Keywords: Vertimill; Secondary grinding; Tertiary grinding; Regrinding.

PhD, Manager Process Engineering, Metso Minerals, York, PA, USA.

Stirred Mills Product Support, Metso Minerals, Belo Horizonte, MG, Brasil.

Process Engineer, Metso Minerals, York, PA, USA.

* Contribuição técnica ao 44ํㅗ Seminário de Redução de Minério de Ferro e Matérias-primas, 15 Simpósio Brasileiro de Minério de Ferro e 2 Simpósio Brasileiro de Aglomeração de Minério de Ferro, 15 a 18 de setembro de 2014, Belo Horizonte, MG, Brasil. 


\section{INTRODUCTION}

The mining industry is faced with a growing challenge of lower ore grades and rising operating costs. In processing these lower grade ores at higher energy costs, the selection of an efficient grinding circuit is critical to the long term profitability of an operation. These realities are continually driving the market towards more energy efficient solutions.

The Vertimill has been widely accepted as an energy efficient alternative for grinding applications, also as an alternative to lower the consumption of grinding media. Figure 1 shows a cut away of the Vertimill and its components. The Vertimill design and the rotation speed of the screw foster the size reduction primarily via attrition, a size reduction mechanism better suited for a more efficient grinding. In addition, because the lack of size reduction by impact, the Vertimill ball consumption is much lower than horizontal Ball Mill.

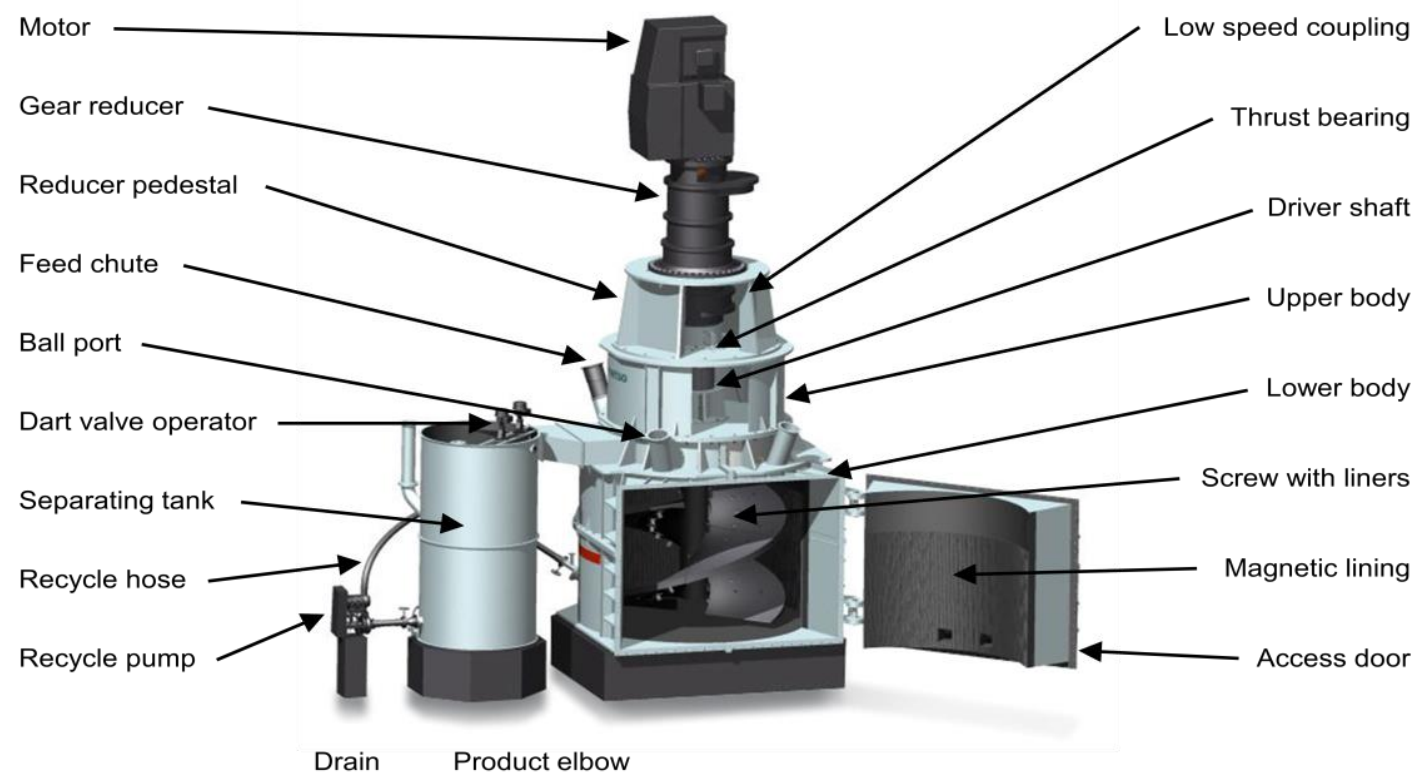

Figure 1: Vertimill Components and Features.

\subsection{Vertimill Applications in the Mining Industry}

To date there are a total of 430 Vertimill installations processing different types of ores ranging from metallic to industrial minerals. As shown in Figure 2, approximately $67 \%$ of the installations are regrind applications where the F80 of circuit feed is typically in the range of $200-100$ microns. There are also applications as secondary and tertiary grinding stage applications with coarser F80's in the range of $600-300$ microns. The success of the Vertimill in such coarser applications has prompted the Mining Industry to consider the use Vertmills in secondary or tertiary grinding stage applications; the requirement being that the circuit F100 must be less than $6 \mathrm{~mm}$ to be considered suitable feed for the Vertimill.

The paper provides a description of current applications of the Vertimill in coarser applications, recent regrind applications processing large tonnages of Iron Ore

* Contribuição técnica ao 44 Seminário de Redução de Minério de Ferro e Matérias-primas, 15 Simpósio Brasileiro de Minério de Ferro e $2^{\circ}$ Simpósio Brasileiro de Aglomeração de Minério de Ferro, 15 a 18 de setembro de 2014, Belo Horizonte, MG, Brasil. 
(Hematite) concentrate. It also presents data that highlights the viability of using the Vertimill as a secondary grinding stage processing a product from SAG Mills or High Pressure Grinding Rolls.

- Grinding

- Secondary: $6 \mathrm{~mm}$ to $75 \mu \mathrm{m}$

- Tertiary: $400 \mu \mathrm{m}$ to $75 \mu \mathrm{m}$

- Regrind: $200 \mu \mathrm{m}$ to $15 \mu \mathrm{m}$

- Flue gas desulphurization: $6 \mathrm{~mm}$ to $20 \mu \mathrm{m}$

- Lime slaking

- Flue gas desulphurization

- Acid neutralization

- Additive
Total HP

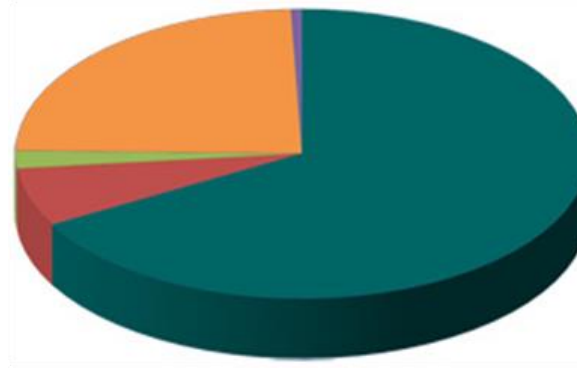

Regrind $-67 \%$

$\square$ Secondary and Tertiary $-24 \%$

- Flue Gas Desulfurization - $6 \%$

$\square$ Lime Slaking $-2 \%$

Other $-1 \%$

Figure 2: Vertimill Applications

\subsection{Existing Vertimill Applications in Coarse Applications}

Table 1 shows a summary of Vertimill applications on primary grinding circuits as secondary and tertiary grinding stage of metallic ores.

Table 1: Vertimill in Secondary and Tertiary Grinding Stage Applications

\begin{tabular}{ccccccc} 
Plant & Ore & Application & VTM Size & Primary Circuit & F80 microns & P80 microns \\
\hline Chino Mines & Copper & Tertiary & VTM-1500 & SABC & 379 & 220 \\
\hline Cannington & Lead-Zinc- Silver & Secondary & VTM-1500 & AG & 190 & 130 \\
\hline Cadia & Copper - Gold & Secondary & VTM-1250 & SABC & 600 & 151 \\
\hline Cadia & Copper - Gold & Tertiary & VTM-3000 & SABC +VTM & 151 & 95 \\
\hline Northland's & Iron - Magnetite & Secondary & 3 X - VTM-3000 & AG & $300-400$ & 34 \\
\hline
\end{tabular}

The use of the Vertimill in coarse applications dates back to the installation of four VTM1250 s at Chino Mines Copper concentrator in the mid 90's (1). Chino's grinding circuit initially consisted of an SABC circuit; four VTM-1250s were subsequently added to the grinding circuit as a tertiary stage to decrease the circuit P80 and increase the copper recovery that had decreased due to significantly increases in plant capacity.

At Cannington's grinding circuit shown in Figure 3 (2), a VTM-1500 operates as a secondary application in conjunction with a primary AG Mill processing of a Lead, Zinc, Silver ore. The installation of the Vertimill came as a result of the need to increase plant capacity as the original design consisted of a single stage AG mill operating in closed circuit with hydrocyclones.

* Contribuição técnica ao 44 Seminário de Redução de Minério de Ferro e Matérias-primas, 15 Simpósio Brasileiro de Minério de Ferro e 2 Simpósio Brasileiro de Aglomeração de Minério de Ferro, 15 a 18 de setembro de 2014, Belo Horizonte, MG, Brasil. 

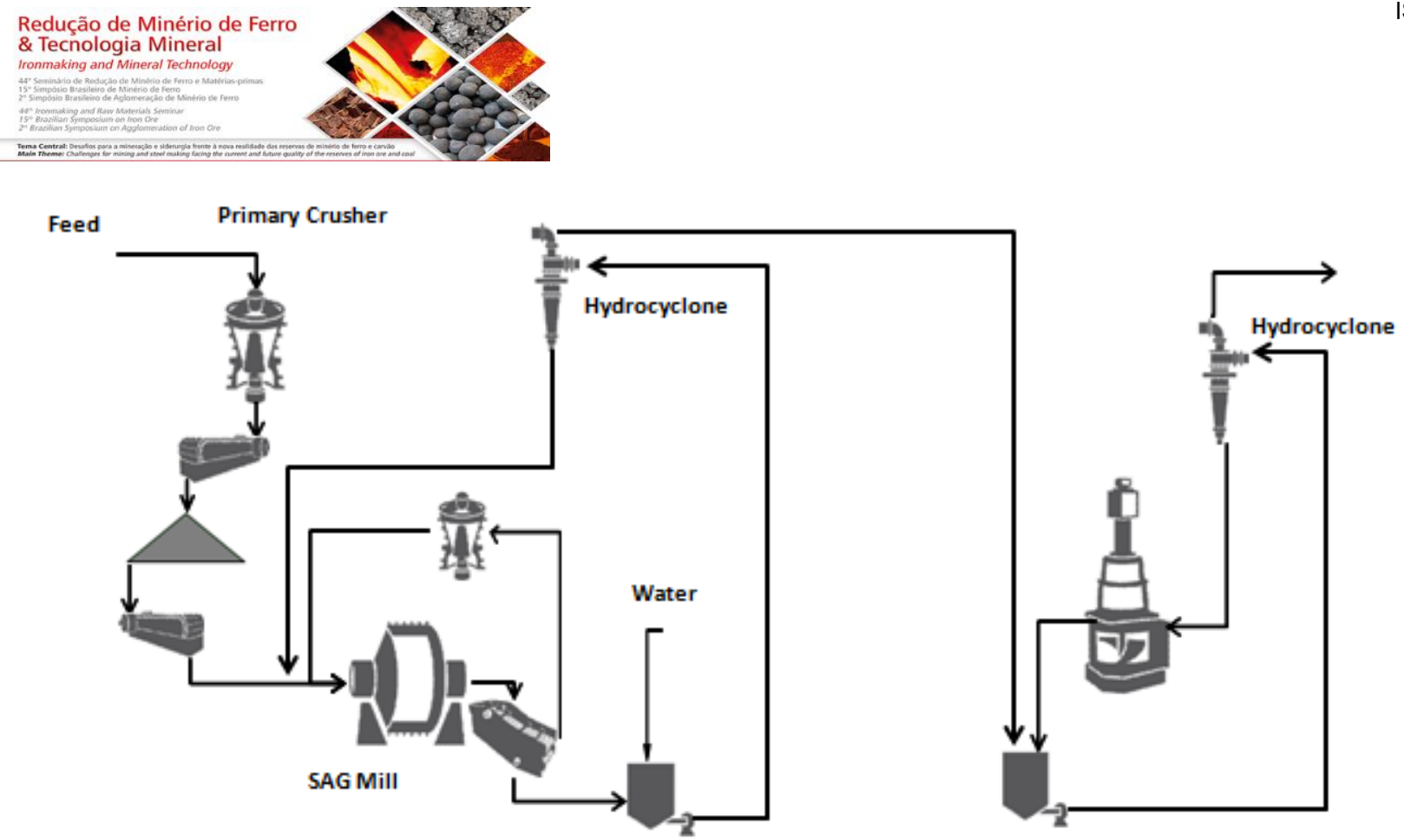

Figure 3: Cannington Grinding Circuit Flowsheet

At Cadia's SABC circuit in Australia, a VTM-1250 was installed as a secondary grinding application in parallel to a ball mill grinding a portion of the cyclone underflow. In this application, a vibratory screen installed underneath the hydrocyclones controls the largest particle size that is fed to the Vertimill. Cadia subsequently added in 2010 one VTM- 3000 as a Tertiary grinding stage to maintain the circuit P80 expected to increase as a result of processing harder ores. Figure 4 shows the flowsheet of Cadia's grinding circuit including the Vertimills operating as secondary and tertiary grinding stages. A picture of Cadia's VTM-3000 installation is shown in Figure 5. It should be noted that since the installation and successfully operation of the first VTM-3000 at Cadia, a total of twenty nine VTM-3000 have been sold for projects around the world for secondary and also regrind applications.

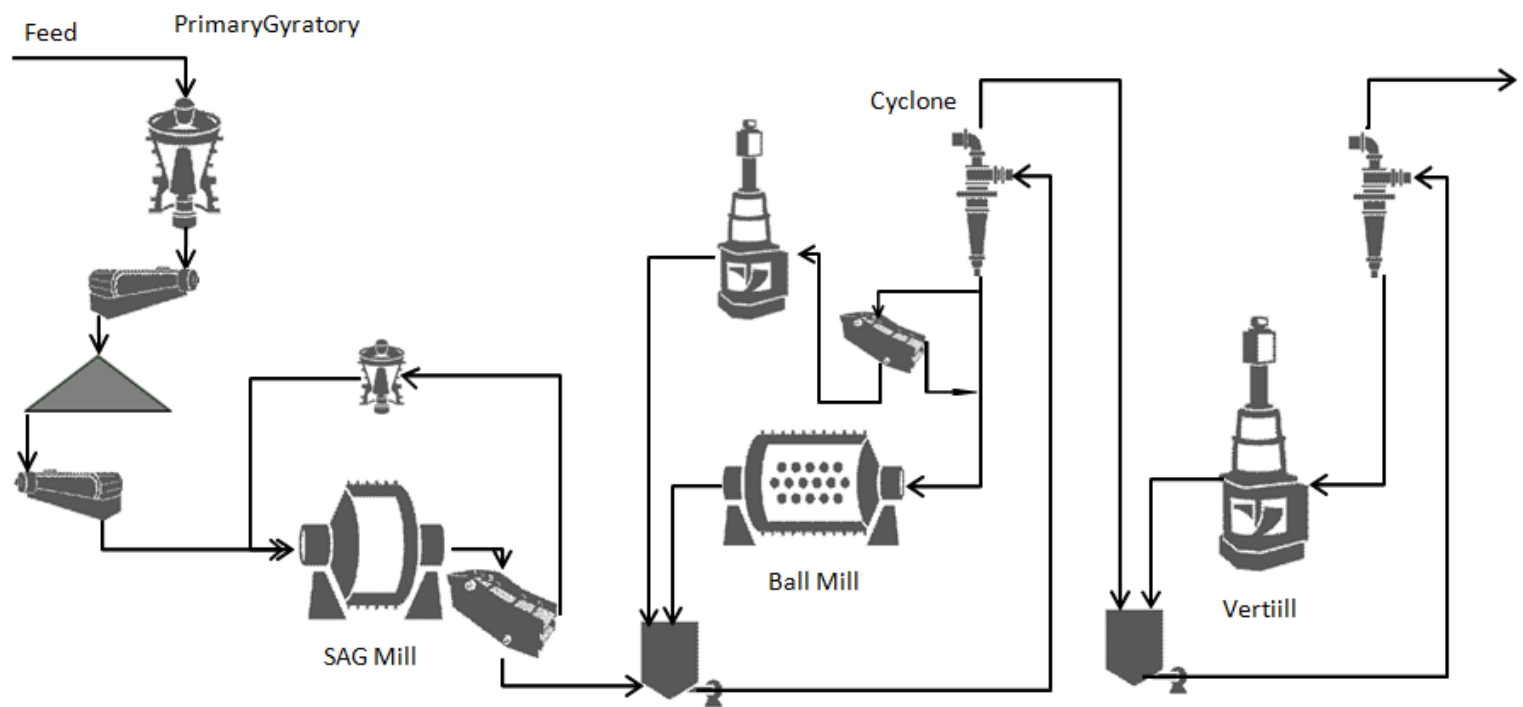

Figure 4: Cadia Grinding Circuit Flowsheet

* Contribuição técnica ao 44 Seminário de Redução de Minério de Ferro e Matérias-primas, 15 Simpósio Brasileiro de Minério de Ferro e 2 Simpósio Brasileiro de Aglomeração de Minério de Ferro, 15 a 18 de setembro de 2014, Belo Horizonte, MG, Brasil. 


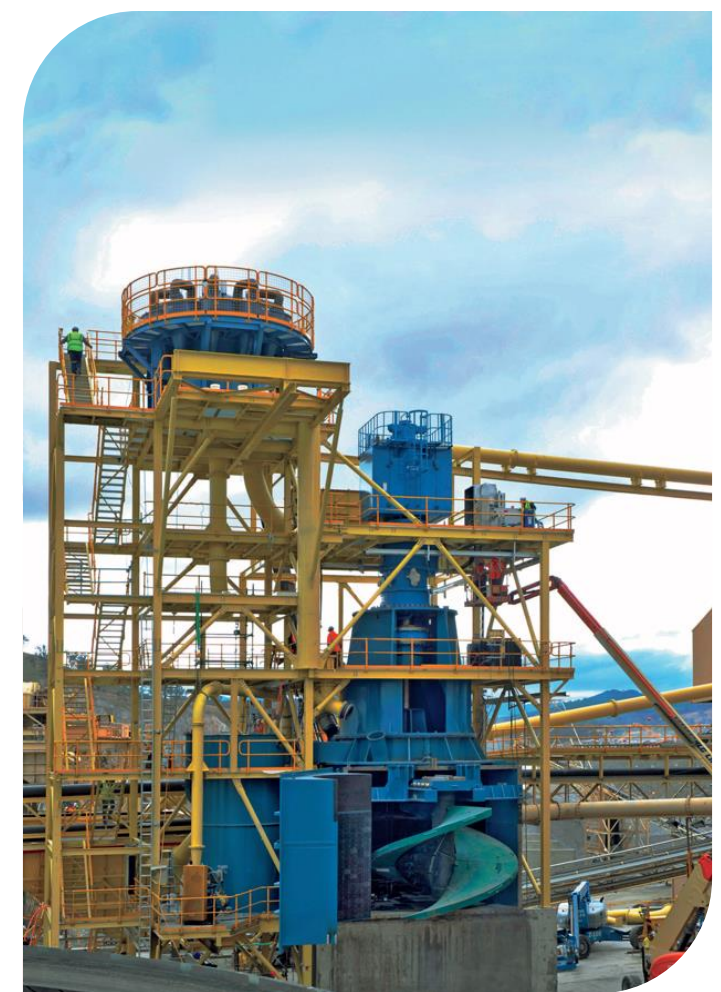

Figure 5: Cadia's VTM-3000 (Tertiary Grinding Stage).

A recent application of the Vertimill as a secondary grinding application for an Iron Magnetite bearing ore at Northlands' operation in Sweden will be described in some detail as it highlights a very attractive option to decrease operating costs for a magnetite processing plant (3). The grinding circuit combines the use of low operating cost grinding units, AG mill and Vertimill, it also takes advantages of the lower mass feed rate to the secondary grinding stage resulting from the upgrading magnetic separation stage. In the opinion of the author such grinding circuit should be considered during prefeasibility studies as it offers a potential alternative to lower plant operating costs.

During the pre-feasibility study of Northlands project the option of installing Vertimills instead of horizontal ball mills for the secondary grinding stage was evaluated. Data considered in the evaluation is shown in Table 2 and the expected cost breakdown between the horizontal ball mill and the Vertimill is shown in Figure 6. Based on the evaluation it was concluded that the installation of three VTM-3000 (6.6 MW) instead of a 9.1 MW horizontal ball mill was the better option as it offered a savings in operating costs of 3.5 million Euros per year.

* Contribuição técnica ao 44 Seminário de Redução de Minério de Ferro e Matérias-primas, 15 Simpósio Brasileiro de Minério de Ferro e $2^{\circ}$ Simpósio Brasileiro de Aglomeração de Minério de Ferro, 15 a 18 de setembro de 2014, Belo Horizonte, MG, Brasil. 
Table 2: Data used in the Evaluation for Northlands Grinding Circuit Assumptions

Cost of Power:

Power Costs Escalation:

Internal Rate of Return:

Labor Cost per Manhour:

Labor Costs Escalation:

Foundation Cost:

Ball Mill 0.75" Balls:

Vertimill 0.75" Cylpebs:

Media Cost Escalation:

Ball Mill Size:

Ball Mill Power:

Ball Mill Auxiliaries Power:

Ball Mill Quantity:

VTM Grinding Mill Size:

VTM Grinding Mill Power:

VTM Grinding Mill Auxiliaries Power:

VTM Grinding Mill Quantity:

Operating Hours per Year

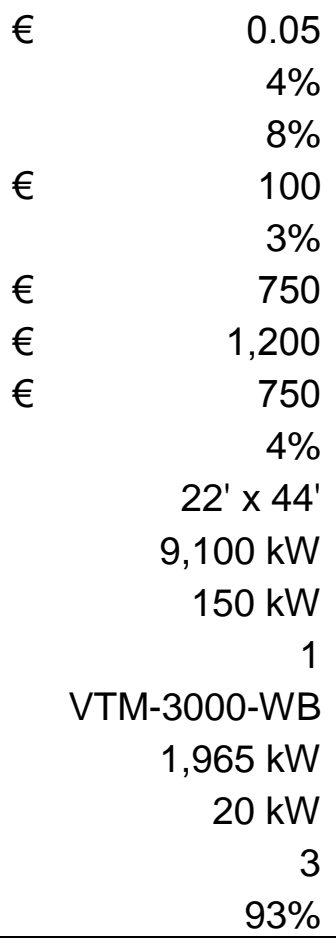

\section{Tapuli OPEX Breakdown Chart}

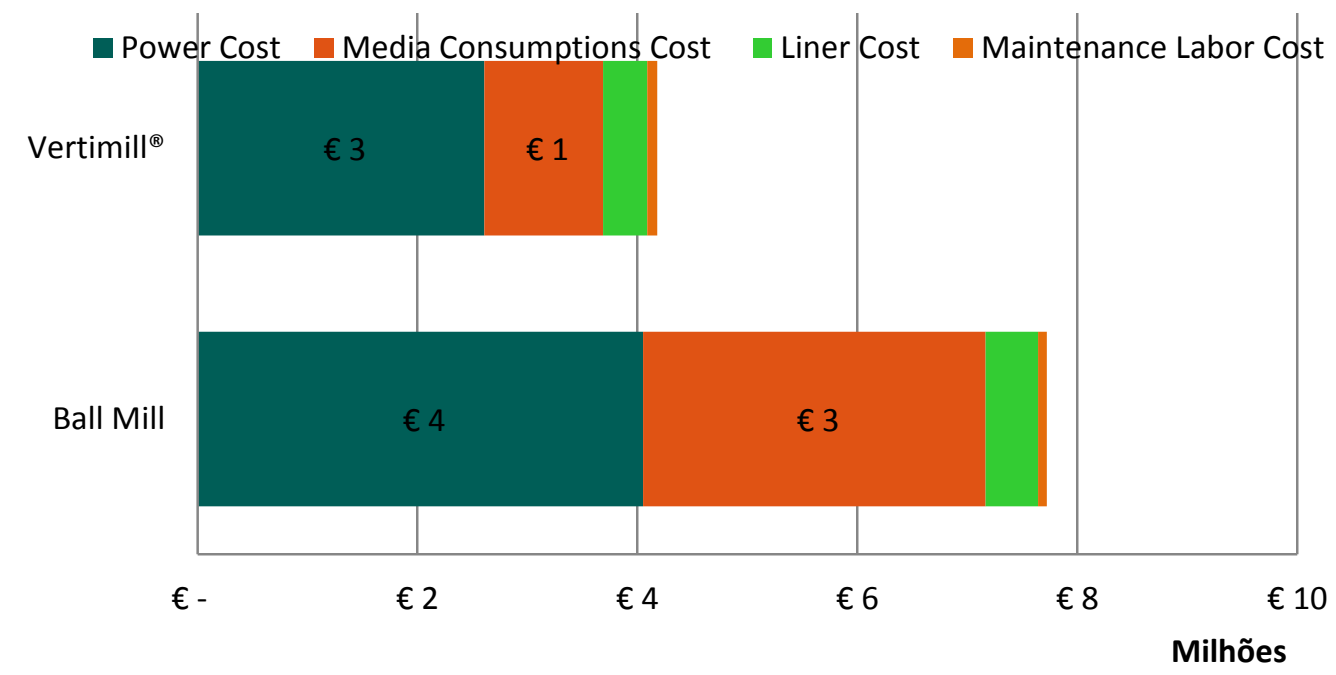

Figure 6: Northland Operating Cost Breakdown Comparison

The operation at Northland commenced at the end of 2012. The flowsheet of the grinding circuit, shown in Figure 7, consisted of $34 \mathrm{ft} \times 17 \mathrm{ft}$ AG Mills followed by a

* Contribuição técnica ao 44 Seminário de Redução de Minério de Ferro e Matérias-primas, 15o Simpósio Brasileiro de Minério de Ferro e 2o Simpósio Brasileiro de Aglomeração de Minério de Ferro, 15 a 18 de setembro de 2014, Belo Horizonte, MG, Brasil. 
cobbing magnetic separation; the magnetic concentrate is then fed to three VTM-3000 operating as a secondary grinding stage and producing a product having a P80 of 34 microns. The product from the Vertimill circuit is then fed to additional stages of magnetic separation to obtain the final concentrate of magnetite that is then filtered by VPA filters prior to shipping. Plant data results to date indicate the target circuit P80 has been met along with the target metallurgical performance.

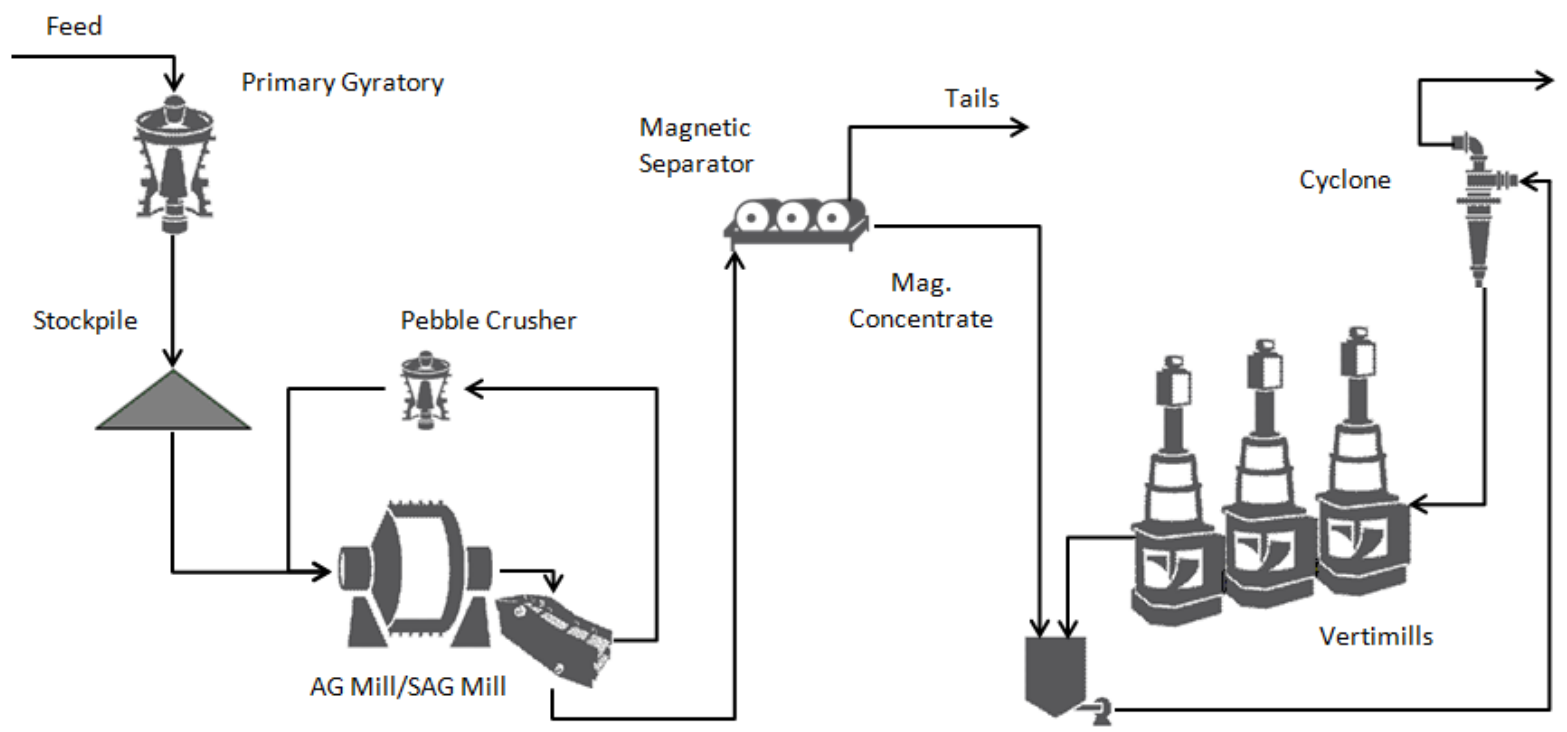

Figure 7: Flowsheet of Northland's Magnetite Grinding Circuit

To date the F80 of the ore fed to most applications of the Vertimill in secondary applications is in the range of 600 to 300 microns as shown in Table 1, such F80 is typical of circuits having an AG mill as the primary stage. Because the potential the Vertimill can offer if installed in much coarser applications with F80's typical of what is being produced from a primary SAG Mill circuit or a High Pressure Grinding Roll circuit has prompted Metso to investigate the viability of using the Vertimill in such applications.

Table 3 shows the results of three continuous Vertimill pilot plant runs using coarser feed samples of Iron and Copper ores; these were conducted at Metso's VTM pilot testing facility in York PA shown in Figure 8. Because the size of the pilot Vertimill the F80 to be tested is still limited by the ball size that can be used, hence limiting testing with much coarser feeds than shown in Table 3. The sample F80's pilot tested is within of the range of T80 produced by the SAG and High Pressure Grinding Roll. The test results confirm the viability of using the VTM as a secondary grinding stage handling such a coarse feed. Also, confirm the expected savings in energy consumption to be in the range of $30 \%$ or higher.

* Contribuição técnica ao 44 Seminário de Redução de Minério de Ferro e Matérias-primas, 15 Simpósio Brasileiro de Minério de Ferro e $2^{\circ}$ Simpósio Brasileiro de Aglomeração de Minério de Ferro, 15 a 18 de setembro de 2014, Belo Horizonte, MG, Brasil. 
Table 3: Vertimill Pilot Plant Test Results with Coarser Feed

\begin{tabular}{|c|c|c|c|c|c|}
\hline Ore & $\begin{array}{c}\text { F100 } \\
\text { microns } \\
\end{array}$ & $\begin{array}{c}\text { F80 } \\
\text { microns }\end{array}$ & $\begin{array}{c}\text { P80 } \\
\text { microns }\end{array}$ & $\begin{array}{l}\text { Ore BWI } \\
\mathrm{kwh} / \mathrm{mt}\end{array}$ & $\begin{array}{c}\% \text { Energy } \\
\text { Savings }\end{array}$ \\
\hline Copper Ore & 4700 & 2013 & 67 & 12.9 & $>25$ \\
\hline Iron Ore & 6700 & 1572 & 103 & 9.7 & $>25$ \\
\hline Copper Ore & 6700 & 1131 & 211 & 18.9 & $>25$ \\
\hline
\end{tabular}

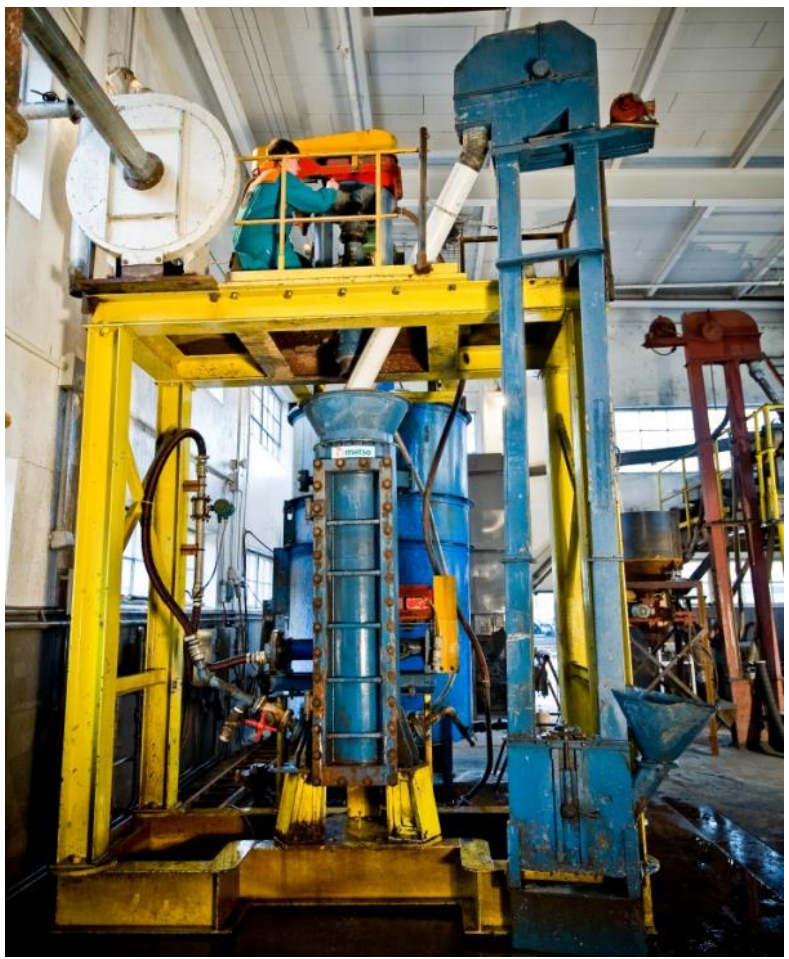

Figure 8: VTM Pilot Plant

\section{REGRINDING APPLICATIONS}

As shown in Figure 2, the Vertimill is well established in the mining industry as the standard grinding mill for regrind applications= A large copper sulphide concentrator with a capacity of $100 \mathrm{ktpd}$ typically requires between two to four large Vertimills to regrind the rougher concentrate. The Iron industry however, because the $30-40 \% \mathrm{Fe}$ head grade, higher tonnage are processed by the regrind circuit requiring several large Vertimills for a $100 \mathrm{ktpd}$ Iron concentrator.

Over the last five years, the Iron industry, processing primarily processing Hematite Iron ores, has adopted the use of Vertimills for the regrind stage. Because the large tonnage of concentrate to be reground the expected savings in operating costs the Vertimill offers is indeed significant when compared to horizontal ball mills, hence enhancing significantly the viability of the project. A typical total cost comparison and expected

* Contribuição técnica ao 44 Seminário de Redução de Minério de Ferro e Matérias-primas, 15 Simpósio Brasileiro de Minério de Ferro e $2^{\circ}$ Simpósio Brasileiro de Aglomeração de Minério de Ferro, 15 a 18 de setembro de 2014, Belo Horizonte, MG, Brasil. 
savings in operating costs over a period of operation for a project with a nominal capacity of $>100 \mathrm{ktpd}$ with a total concentrate production of $75 \mathrm{ktpd}$ is shown in table 4 . Because the power requirements to regrind the Iron concentrate and the available Vertimill size to date, several Vertimills are required to pull the equivalent power that a single regrind ball mill can pull. For instance to replace a $12 \mathrm{MW}$ ball mill, Four VTM3000 or Eight VTM-1500 are required. Prior to the development of the VTM-3000, the largest VTM built was the VTM-1500. As a result, project "A", processing Hematite ore, required 16-VTM-1500 to replace two large $26 \mathrm{ft}$ Ball Mills. Another larger capacity Iron ore "Plant B", required 14 VTM-3000 for a similar application. As several Vertimills are required, the layout and design needs to be properly evaluated to ensure a proper distribution of the fresh feed to each of the Vertimills. A typical lay-out of the Vertimills is shown in Figure 9, having a such number of units provides operating flexibility and minimal disruption to the plant capacity as shutting down a unit would only affect a fraction of the plant capacity. Project "A" is scheduled to be commissioned in 2014.

Table 4. Cost Comparison Regrind Circuit

$\begin{array}{ll}\text { Trade off Analysis - two } 26 \mathrm{ft} \text { Ball Mills vs } 16 \text { VTM- } \\ \text { Plant : "A" } & \text { "A" } \\ \text { Circuit } & \text { Regrind Iron Concentrate } \\ \text { Circuit Capacity : } & 3042 \text { mtph of Concentrate }\end{array}$

\begin{tabular}{|c|c|}
\hline Equipment and Installation Costs & $\begin{array}{c}\text { Cost differential between two 26' Ball Mills vs } \\
\text { 16 VTM-1500 \$ US Dollars }\end{array}$ \\
\hline Installation & $-1,320,000$ \\
\hline Foundations & $-1,120,000$ \\
\hline Equipment & $9,260,000$ \\
\hline Transportation & $-100,000$ \\
\hline Accessories & $-800,000$ \\
\hline \hline Sub-Total Equipment and Installation & $5,920,000$ \\
\hline
\end{tabular}

\begin{tabular}{|c|c|}
\hline Operating Costs (one Year) & $\begin{array}{c}\text { Cost differential between two 26' Ball Mills vs } \\
\text { 16 VTM-1500 \$ US Dollars }\end{array}$ \\
\hline Energy Consumption per year & $-7,060,385$ \\
\hline Ball Consumption per year & $-4,783,061$ \\
\hline Liners & $-150,000$ \\
\hline Man power for liner change & $-37,200$ \\
\hline \hline Sub-Total Operating Costs & $-12,030,646$ \\
\hline
\end{tabular}

\begin{tabular}{|c|c|}
\hline \hline Sub-Total Equipment and Installation & $5,920,000$ \\
\hline \hline \multicolumn{2}{|c|}{} \\
\hline Sub-Total Operating Costs & $-12,030,646$ \\
\hline IRR & 0.49 years \\
\hline
\end{tabular}

* Contribuição técnica ao 44 Seminário de Redução de Minério de Ferro e Matérias-primas, 15 Simpósio Brasileiro de Minério de Ferro e $2^{\circ}$ Simpósio Brasileiro de Aglomeração de Minério de Ferro, 15 a 18 de setembro de 2014, Belo Horizonte, MG, Brasil. 


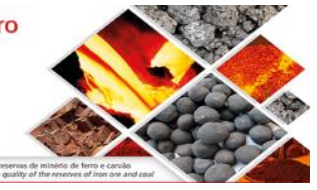

Because the significant impact in lowering the operating costs of the regrinding stage, the Vertimill is expected to be embraced by the Iron Mining industry to the point that it would become the equipment of choice for the regrind circuit. As these plants having several Vertimills are commissioned, the experience to be gained in terms of properly distributing the fresh feed and also in the maintenance practices will play an important role as the Vertimill is applied in primary grinding circuits processing the product from a SAG mill or an high pressure grinding roll.

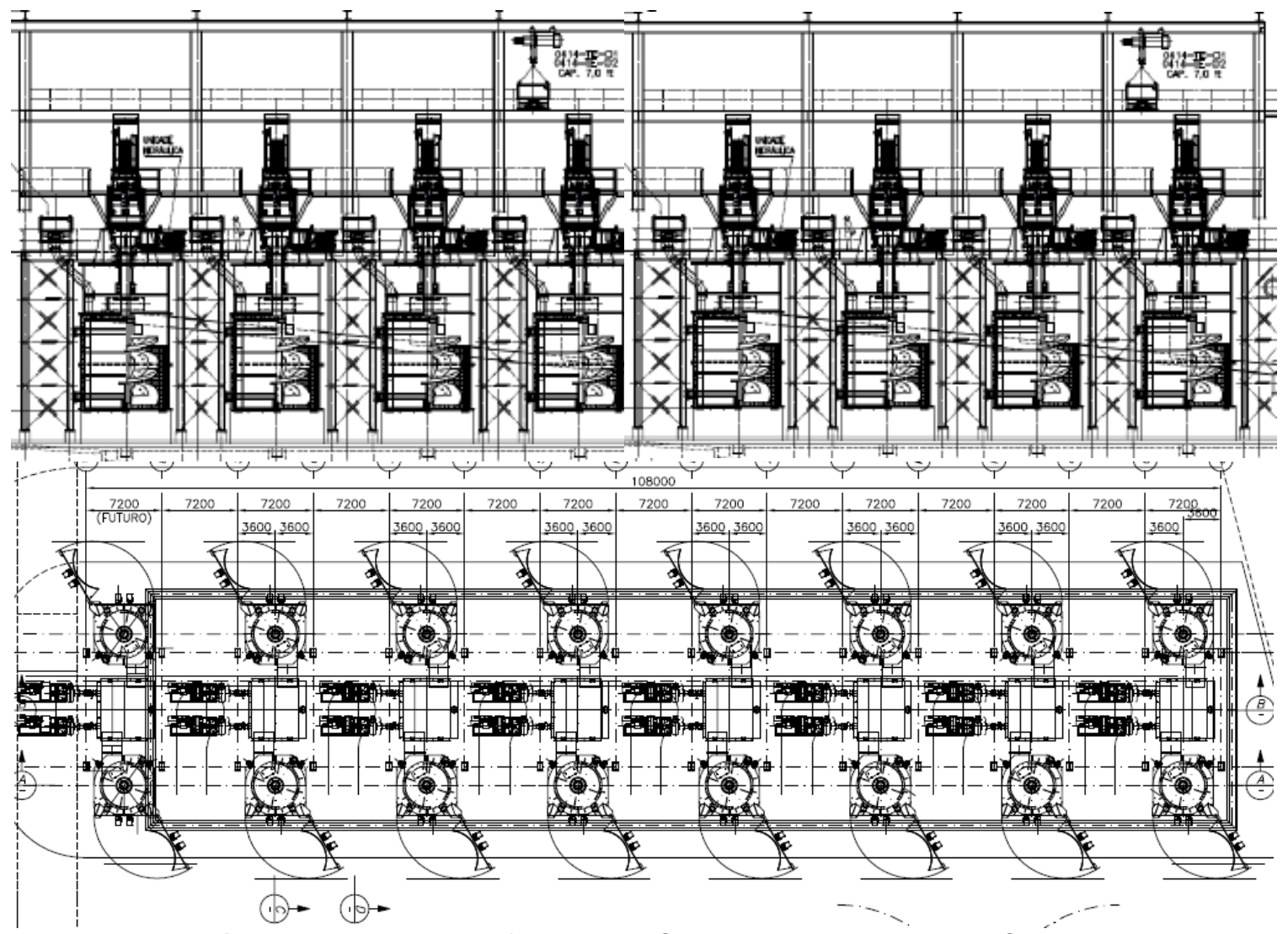

Figure 9. Plant Layout for a Large Capacity Vertimill Regrind Circuit

\section{WHAT IS NEXT}

The application of the Vertimill as a secondary grinding stage following a SAG / AG mill and High Pressure Grinding rolls has the potential to significantly decrease a concentrator's operating costs. Pilot plant tests and data from current Vertimill installations in secondary applications confirm the viability of the use of the Vertimill in secondary grinding applications processing the product from SAG Mills, HPGR or Rod Mills. A trade off analysis for a 120 kptd copper concentrator considering twelve VTM4500 instead of four $12.5 \mathrm{MW}-24 \mathrm{ft}$ Ball Mills, indicates a significant decrease in operating costs with a IRR of approximately two years and total cost of ownership over a period of ten years of approximately \$US 200 million. Metso is striving to continuously develop larger size Vertimills to minimize the number required for a secondary stage grinding duty. The VTM-4500 (HP) is already a reality, in fact two units are scheduled to be commissioned late in 2014. Currently larger VTM sizes are currently in Metso's drawing board.

* Contribuição técnica ao 44 Seminário de Redução de Minério de Ferro e Matérias-primas, 15 Simpósio Brasileiro de Minério de Ferro e 2 Simpósio Brasileiro de Aglomeração de Minério de Ferro, 15 a 18 de setembro de 2014, Belo Horizonte, MG, Brasil. 


\section{CONCLUSIONS}

As the industry seeks ways to lower operating costs it is expected the Vertimill to be embraced as an option for a secondary grinding to further lower a concentrator's operating costs. Its impact is expected to be significant. As larger Vertimill sizes are developed, the number of Vertimills required to replace the equivalent power of a horizontal ball mill will decrease and consequently improving the project economics.

\section{BIBLIOGRAPHY}

1 Vanderbeek J. Tertiary Grinding Circuit Installation at Chino Mines Company, SME, Comminution Practices, Chapter 31, 1998.

2 Jankovic A, Valery W, Clarke G. Design and Implementation of an AVC Grinding Circuit at BHP Billiton Cannington, SAG 2006 Conference

3 Allen J. Arvidson B. Design and Selection of Vertimill @ Grinding Mills for Northland Resources' Kaunisvaara Project. Private Communication.

* Contribuição técnica ao 44 Seminário de Redução de Minério de Ferro e Matérias-primas, 15 Simpósio Brasileiro de Minério de Ferro e $2^{\circ}$ Simpósio Brasileiro de Aglomeração de Minério de Ferro, 15 a 18 de setembro de 2014, Belo Horizonte, MG, Brasil. 